\title{
CNGRC Peptide-TNF Alpha Conjugate
}

National Cancer Institute

\section{Source}

National Cancer Institute. CNGRC Peptide-TNFAlpha Conjugate. NCI Thesaurus. Code C48383.

A cytokine-peptide conjug ate composed of the cytokine tumor necrosis factor alpha (TNF-alpha) chemically linked to the peptide CNGRC. The peptide moiety CNGRC, a lig and for the membrane-bound metalloprotease CD13, binds to endothelial cells of the angiog enic vasculature that express CD13 (also known as aminopeptidase N); subsequently, the TNF-alpha moiety induces apoptosis in endothelial cells expressing CD13, thereby inhibiting tumor-associated angiogenesis. ( $\mathrm{NCI05)}$ 